\title{
NEPALESE LANDRACES OF SPONGE GOURD FOR THE PRODUCTION OF TENDER FRUITS
}

Bal K. Joshi ${ }^{1}$, Radha K. Tiwari ${ }^{1}$, Hari B. KC ${ }^{1}$, Madhusudan Ghale ${ }^{2}$, Sanjaya Gyawali ${ }^{3}$ and Madhusudan P. Upadhyay ${ }^{1}$

\begin{abstract}
Evaluation of landraces is necessary for better management of agricultural biodiversity onfarm. The objective was to evaluate the farmers' named landraces of sponge gourd that are being maintained on-farm for tender fruit production. A total of 21 sponge gourd landraces collected from six districts of Nepal were evaluated in a randomized completeblock design with three replications at Agriculture Research Station, Malepatan, Pokhara, Nepal. These landraces were significantly $(p=0.05)$ different for first harvest days $(p=$ $0.05)$ and fruit yield perplant $(p=0.05)$, highly significant $(p<0.01)$ for last harvest days, fruit-skin thickness, flesh thickness, fruit length, fruit perimeter, fruit weight and fruit number. Variation for tender fruits among these landraces can be utilized for improving the genotypes of sponge gourd as well as for long-term production in diverse environments.
\end{abstract}

Key words: Evaluation, fruit vegetable, Luffa cylindrica, sponge gourd landraces

\section{INTRODUCTION}

Luffa [Luffa cylindrica (L.) Roem Syn. L. aegyptiaca Mill.], commonly called sponge gourd, loofah or dishcloth gourd, is a member of cucurbitaceae family. It has the multiple use values. For examples, tender fruit is used as vegetable, whereas mature sponge gourd is used for cleaning utensils and in bathroom. Fresh juice from leaf is used for healing wounds and also used as primer in doors and windows by Nepalese farmers. Dried sponge, which is fibrous, is used in commercial filters and for insulation (Porterfield, 1955). The seeds yield colorless, odorless, tasteless oil that can be used in cooking (Porterfield, 1955).

In Nepal, two cultivated species (L. cylindrica and L. acutangula) and one wild species (L. echinata) are found. National Genebank (NGB), Khumaltar, Nepal, has conserved 60 accessions of sponge gourd (Gupta et al., 2000). Nepalese farmers call Ghiraula for Luffa cylindrica. It is a summer season vegetable grown from Tarai (lower belt) to High-hill in Nepal. Mid-hill is the most important zone where most of the farmers grow sponge gourd. Farmers let vines climb on living tree, dead branches, walls or roof.

\footnotetext{
${ }^{1}$ Genebank-NARC, Khumaltar, PO Box 3055, Kathmandu, joshibalak@yahoo.com

${ }^{2}$ Agriculture Research Station-NARC, Malepatan, Pokhara (Current address: Maharajghunj, Kathmandu) Nepal

${ }^{3}$ Local Initiatives for Biodiversity, Research and Development, PO Box 324, Pokhara, Nepal, currently in abroad.
} 
The crop is cross-pollinated; therefore, insect pollinator is necessary for better fruit production. The flowers are produced in the leaf axil with four to 20 staminate flowers and one pistillate flower in the same axil. The flower opens in the early morning and remains open only for one day (Porterfield, 1955). L. cylindrica and L. acutangula are monoecious (Singh 1958), but other species of Luffa have four types of inflorescences: monoecious, andro-monoecious, gynoecious and hermaphroditic (Davis, 1996).

Despite its importance as a vegetable, limited efforts have been made to improve sponge gourd in Nepal. Only one variety, Kantipure, has been released in Nepal (NARC, 2000). Landrace diversity and farmers' preferred traits of sponge gourd were studied by Rana et al. (2000a, b). Based on diversity of Nepalese landraces, descriptors for sponge gourd were developed by Joshi et al. (2004). On-farm agromorphological characterization was done by Bajracharya et al. (1999), Pandey et al. (2003), and Yadav et al. (2003). Cruz et al. (1997) studied correlation and variability of morphological and biochemical characters, and reported that, $L$. acutangula had lower overall variation compared to L. cylindrica.

Existence of many landraces indicates that there is great possibility to increase yield through improvement in genetic and agronomic practices. Some landraces are better for sponge and others are good for fruit vegetables. Landraces are adapted to tropical to subtropical to temperate climate. As genetic erosion of landrace diversity is increasing (Joshi et al., 2005), their evaluation has become a necessity for on-farm and ex-situ conservation, at least, for most important types. The primary objective of this study was to evaluate landraces collected from different areas of Nepal for tender fruits that can be used as a vegetable.

\section{MATERIAL AND METHODS}

A total of 21 landraces, collected from six districts of Nepal were evaluated (Table 1 ) in 2004. Among these, 15 landraces were collected directly from two agroecological sites, i.e., Begnas in Kaski district and Kachorwa in Bara district. Six diverse landraces were selected from National Genebank (NGB), Khumaltar, Nepal, on the basis of the collection sites and local names. The name of three collections from Bara was the same, i.e., Ujarka, even though there was variation in seed color. Therefore, these three collections were prefixed with the first name initial of the farmer who provided the seeds, e.g., Ujarka-B. Some of them have been characterized on-farm by Pandey et al. (2003) and Yadav et al. (2003).

Experiment was conducted in a randomized complete-block design with three replications at Agriculture Research Station, Malepatan, Pokhara in 2004. Coordinates of experimental site are $28^{\circ} 15^{\prime} \mathrm{N}$ latitude and $84^{\circ} 00^{\prime} \mathrm{E}$ longitude at an altitude of $848 \mathrm{~m}$ above sea level in a subtropical area having loam soil. Three to five plants of each landrace were maintained in each plot. Seeds were sown directly in pits containing three kg compost. Plants were spaced at $2.5-x 2.0-\mathrm{m}$. Later, $10 \mathrm{~g}$ urea/plant was top-dressed at one and half month after seeding. Each plant was supported by a dead tree branch. Manual weeding and guarding were done to protect the fruits from weeds and birds. 
Table 1. Landraces of sponge gourd evaluated in Malepatan, Pokhara, Nepal

\begin{tabular}{|c|c|c|c|}
\hline Landrace & Farmer /donor name & Collection site & Altitude, m \\
\hline Basaune & Diversity fair & Begnas, Kaski & 848 \\
\hline Harihar Tagwa Bhadaiya & Sharada Devi Jaisawal & Kachorwa, Bara & 85 \\
\hline Hariharka & Maha Narayan Prasad Yadav & Kachorwa, Bara & 85 \\
\hline Hariyo Basaune & Debendra Adhikari & Begnas, Kaski & 848 \\
\hline Hariyo Chhoto & Bhoj Raj Poudel & Begnas, Kaski & 848 \\
\hline Hariyo Lamo & Krishna Maya Tiwari & Begnas, Kaski & 848 \\
\hline Hariyo Bose & Shiva Raj Subedi & Begnas, Kaski & 848 \\
\hline Jangali Ghiraula & NGB, Khumaltar & Ratnapuri-1, Bara & 250 \\
\hline Jhimni & NGB, Khumaltar & Ratnapuri-1, Bara & 250 \\
\hline Jhingani & NGB, Khumaltar & Laxmipur, Udaypur & NAł \\
\hline Lamka Ujarka & Pun Kumari Devi Gupta & Kachorwa, Bara & 85 \\
\hline Lamo Bose & Dev Raj Poudel & Begnas, Kaski & 818 \\
\hline Sagputti Ghiraula & NGB, Khumaltar & Santapur-4, Rautahat & 300 \\
\hline Sano Ghiraula & NGB, Khumaltar & Pipladi-6, Kanchanpur & NA \\
\hline Seto Basaune & Dev Raj Poudel & Begnas, Kaski & 848 \\
\hline Seto Bose & Bishnu Prasad Tiwari & Begnas, Kaski & 848 \\
\hline Seto Lamo & Hari Maya Poudel & Begnas, Kaski & 848 \\
\hline Toriya & NGB, Khumaltar & Garamani, Jhapa & NA \\
\hline Ujarka-B & Badri Prsad Kushwaha & Kachorwa, Bara & 85 \\
\hline Ujarka-N & Nisahara Khatun & Kachorwa, Bara & 85 \\
\hline Ujarka-R & Raj Kali Devi Gupta & Kachorwa, Bara & 85 \\
\hline
\end{tabular}

$\lceil\mathrm{SN}=$ Serial Number. $\ddagger$ NA = Not available. Plant Genetic Resources Unit. NGB = National Genebank.

Climatic parameters (temperature, rainfall and relative humidity) during the growing period were recorded and analyzed (Figure 1). Eleven traits related to tender fruit production were recorded as described by Joshi et al. (2004a). Details of traits studied are given in Table 2. Sample size to measure the data ranged from 3 to 5 fruits and/or 3 to 5 plants. Three fruits from each plant were left for seed production; therefore, actual tender fruit yield was less by three fruits. Selfed seeds of each landrace were given to NGB, Khumaltar for ex-situ conservation. Data were subjected to multivariate analysis of variance (MANOVA), analysis of variance (ANOVA) and mean separation (Duncan's New Multiple Range Test). Data were processed in MS Excel and analyzed using MINITAB and MSTATC. 


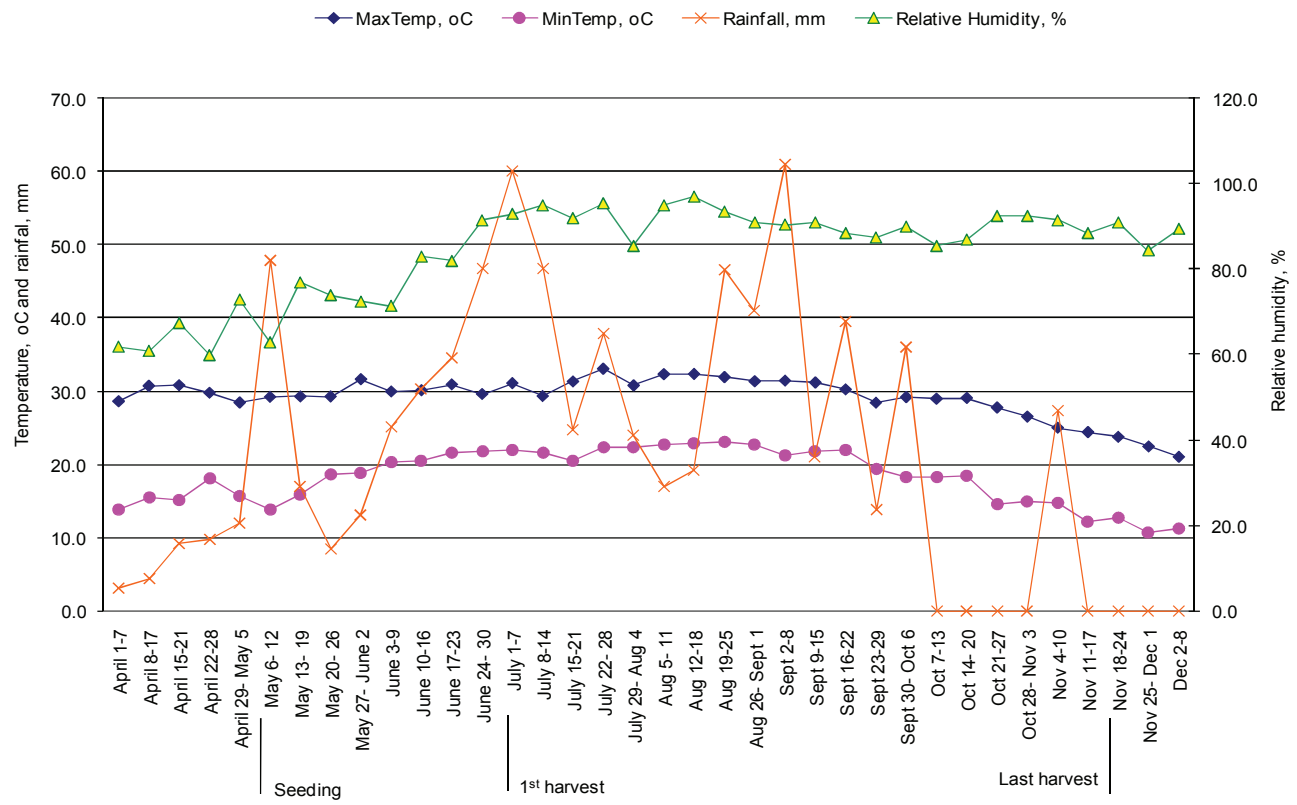

Figure 1. Climatic parameters (weekly average) during growing season of sponge gourd in Malepatan, Pokhara, Nepal.

Table 2. Evaluation descriptors for sponge gourd used in this study

\begin{tabular}{|c|c|c|}
\hline SN & Descriptor & Method \\
\hline 1 & Days to emergence & $\begin{array}{l}\text { Number of days between seeding to emergence. Recorded date of } \\
\text { seeding and date of emergence to calculate }\end{array}$ \\
\hline 2 & $\begin{array}{l}\text { Days to first harvest for } \\
\text { vegetable use }\end{array}$ & Number of days between seeding and first harvest for vegetable use \\
\hline 3 & $\begin{array}{l}\text { Days to last harvest for } \\
\text { vegetable use }\end{array}$ & Number of days between seeding and last harvest for vegetable use \\
\hline 4 & $\begin{array}{l}\text { Harvesting period of fruit for } \\
\text { vegetable use }\end{array}$ & Days to last harvest minus days to first harvest \\
\hline 5 & Fruit skin thickness & $\begin{array}{l}\text { Average of three fruits of different plants measured at central part of } \\
\text { fruit during harvest for vegetable use }\end{array}$ \\
\hline 6 & Flesh skin thickness & $\begin{array}{l}\text { Average of three fruits of different plants measured at central part of } \\
\text { fruit during harvest for vegetable use }\end{array}$ \\
\hline 7 & Fruit length & $\begin{array}{l}\text { Average of } 3 \text { fruits of different plants measured from blossom end to } \\
\text { stem end during fruit harvest for vegetable use }\end{array}$ \\
\hline 8 & Fruit perimeter & $\begin{array}{l}\text { Average perimeter of three fruits of different plants measured in three } \\
\text { parts (petiole end, center and blossom end) }\end{array}$ \\
\hline 9 & Fruit weight & $\begin{array}{l}\text { Average weight of three fruits from different plants during harvest for } \\
\text { vegetable use }\end{array}$ \\
\hline 10 & Fruit number/plant & $\begin{array}{l}\text { The number of fruits suitable for vegetable use during crop season. } \\
\text { Average of three plants }\end{array}$ \\
\hline 11 & Fruit yield/plant & $\begin{array}{l}\text { Weight of total fruits harvested for vegetable use. Average of three } \\
\text { plants }\end{array}$ \\
\hline
\end{tabular}

$\mathrm{SN}=$ Serial number 


\section{RESULTS AND DISCUSSIONS}

The landraces represented two eco-regions, Mid-hill and Tarai of Nepal. While Tarai has tropical climate, Mid-hill has sub-tropical to temperate climate. All these landraces grew well and produced fruits in this sub-tropical experimental site. All climatic parameters during crop growing period were higher than other period (Figure 1). During initiation of fruit harvest for use as a vegetable, minimum and maximum temperature, rainfall and relative humidity were high. It indicated that temperature was an important factor for tender fruit production. Davis (1996) reported that cool night and warm day were favorable for high yields and cool night, warm day, and humidity induced female flowers in sponge gourd.

Multivariate analysis of variance indicated the overall significance of differences (Wilk's $\mathrm{P}=<0.001$ ) among these landraces. After obtaining a significant multivariate test, we examined the univariate $F$ test for each variable to interpret the respective effects. Analysis of variances indicated that these landraces were significantly $(p=0.05)$ different for first harvest days and fruit yield/plant, highly significant $(p<0.01)$ for last harvest days, fruit-skin thickness, flesh thickness, fruit length, fruit perimeter, fruit weight and fruit number, but were not significant for days to germination (Tables 3 and 4).

Tender fruits were harvested the earliest from the Kachorwa's landraces. Among these landraces, Jhingani produced fruits ready for harvest within the shortest time and Lamo Bose took the longest time to produce fruit for harvest. Standard deviation of days to first harvest was the highest in landraces collected from NGB, Khumaltar, probably because these collections consisted of landraces collected from different locations. The earliest harvest may help get high market price and provide green vegetable during dry seasons. Many agronomical and indigenous practices can be used for better crop harvest. For example, transplants result in a better plant stand than the direct-seeded plants (Davis, 1996). He reported that yield from transplanting was 1.2 times higher than those from direct-seeded plants, however transplanting is not practiced by farmers in Nepal. Farmers in Nepal hang some weight, usually long chain of maize spadix on vine of sponge gourd for higher fruit yield and earlier fruiting and some farmers pinch the vine for the same purpose in Nepal. This traditional knowledge needs to verify. Tender fruits were harvested up to 169.3 days after seeding from Toriya. Sagputti Ghiraula had the shortest period from seeding to last harvest. The collections from NGB had a high standard deviation for days to last harvest (Table 3). The period of tender fruit harvest of all landraces is given in Figure 2. Toriya had the longest fruit-harvesting period, followed by Hariyo Bose. Jhimni had the shortest period of fruit harvest. Fruit harvesting period is important for getting higher yield as well as for regular supply of green vegetables. Farmers who grow very few plants in their home gardens prefer varieties having long harvesting period. Landraces from Kachorwa had longer period of fruit harvest compared to other sites.

Farmers in Begnas and Kachowra did not report fruit-skin thickness as their selection criterion. However, fruit having thin skin is preferred for cooking purposes. Variation in fruit skin among these landraces indicated the possibility of 
selecting genotypes of desired skin thickness. Fruit-skin thickness ranged from 2.01 to $3.61 \mathrm{~mm}$ and it is suggested to explore the role of skin thickness on fruit shelf life. Seto Bose had the thickest and Jhimni the thinnest skin. Standard deviation of skin thickness was similar among these landraces. Flesh thickness is an important trait as compared with skin thickness. Means of flesh thickness were not significantly different among Kachorwa landraces, whereas the collections from Kaski and NGB had significantly different flesh thickness. Variation was higher in NGB collections. Lamo Bose had the thickest flesh, followed by Jangali Ghiraula (edible and available in Bara district), and Sagputti Ghiraula had the thinnest flesh (Table 3).

Table 3. Phenologcial, fruit skin and flesh characteristics of sponge gourd landraces

\begin{tabular}{|c|c|c|c|c|c|c|c|c|c|c|c|}
\hline \multirow{2}{*}{\multicolumn{2}{|c|}{ SN Landrace }} & \multicolumn{4}{|c|}{ Germination, $\mathrm{d}$ 1st harvest, $\mathrm{d}$} & \multicolumn{2}{|c|}{ Last harvest, d } & \multicolumn{2}{|c|}{$\begin{array}{l}\text { Fruit skin thickness, } \\
\mathrm{mm}\end{array}$} & \multicolumn{2}{|c|}{ Flesh thickness, cm } \\
\hline & & Mean & SD & Mean & SD & Mean & SD & Mean & SD & Mean & SD \\
\hline \multicolumn{12}{|c|}{ Begnas, Kaski } \\
\hline 1 & Hariyo Chhoto & $7.67 \mathrm{~b}$ & 1.16 & 106.3abcd & 14.01 & 163.0ab & 6.24 & $2.440 \mathrm{cde}$ & 0.51 & $4.380 \mathrm{bcde}$ & 0.54 \\
\hline 2 & Hariyo Basaune & $8.00 \mathrm{~b}$ & 0.00 & 94.0abcde & 7.00 & $156.3 a b c$ & 11.50 & 3.000abcd & 0.33 & $4.200 \mathrm{bcde}$ & 0.29 \\
\hline 3 & Hariyo Lamo & $7.00 \mathrm{~b}$ & 0.00 & 96.0abcde & 11.36 & 153.3abcd & 10.79 & $2.890 \mathrm{abcde}$ & 0.19 & $4.010 \mathrm{bcde}$ & 0.52 \\
\hline 4 & Lamo Bose & $9.20 \mathrm{ab}$ & 3.54 & $112.4 a$ & 1.41 & 150.2abcd & 31.80 & $3.300 \mathrm{abc}$ & 0.47 & $4.930 \mathrm{~b}$ & 0.87 \\
\hline 5 & Hariyo Bose & $7.67 \mathrm{~b}$ & 1.16 & 90.3abcde & 7.09 & 155.0abc & 6.56 & 2.890abcde & 0.84 & 3.910 cde & 0.40 \\
\hline 6 & Seto Bose & $8.33 b$ & 0.58 & 105.7abcd & 5.13 & 154.7abc & 15.31 & $3.610 \mathrm{a}$ & 0.10 & $4.470 \mathrm{bcd}$ & 0.27 \\
\hline 7 & Seto Lamo & $7.00 \mathrm{~b}$ & 0.00 & 103.7abcd & 9.87 & 154.0abc & 5.29 & $2.890 \mathrm{abcde}$ & 0.54 & 3.820de & 0.34 \\
\hline 8 & Seto Basaune & $8.33 b$ & 0.58 & 106.7abcd & 6.03 & $162.3 a b$ & 9.81 & $3.440 \mathrm{ab}$ & 0.20 & $4.000 \mathrm{bcde}$ & 0.22 \\
\hline \multirow{3}{*}{9} & Basaune & $8.33 b$ & 0.58 & 97.30abcde & 16.20 & 151.3abcd & 5.77 & $2.500 \mathrm{cde}$ & 0.50 & $4.430 \mathrm{a}$ & 0.49 \\
\hline & Mean & 7.95 & 0.70 & 101.38 & 7.25 & 155.57 & 4.43 & 3.00 & 0.40 & 4.23 & 0.35 \\
\hline & NGB, Khumaltar & & & & & & & & & & \\
\hline 1 & Jhingani & $11.67 a b$ & 6.43 & $80.70 \mathrm{e}$ & 10.60 & 148.3abcd & 9.50 & 2.330de & 0.58 & $3.470 \mathrm{e}$ & 0.79 \\
\hline 2 & Toriya & $7.00 \mathrm{~b}$ & 0.00 & 101.3abcde & 5.69 & $169.3 a$ & 6.35 & 3.220abcd & 0.19 & $3.700 \mathrm{de}$ & 0.16 \\
\hline 3 & Jangali Ghiraula & $11.67 a b$ & 5.51 & $111.3 a b$ & 19.10 & 165.0ab & 7.00 & $2.670 \mathrm{bcde}$ & 0.76 & $4.820 \mathrm{bc}$ & 0.92 \\
\hline 4 & Jhimni & $6.50 \mathrm{~b}$ & 0.00 & 104.5abcd & 14.80 & $138.3 \mathrm{~cd}$ & 0.00 & $2.010 \mathrm{e}$ & 0.00 & $4.570 \mathrm{bcd}$ & 0.42 \\
\hline 5 & Sano Ghiraula & $8.00 \mathrm{~b}$ & 0.71 & 103.0abcde & 21.20 & $138.3 \mathrm{~cd}$ & 0.00 & $2.510 \mathrm{cde}$ & 0.71 & $4.550 \mathrm{bcd}$ & 0.04 \\
\hline \multirow{3}{*}{6} & Sagputti Ghiraula & $11.67 a b$ & 6.43 & 85.70de & 11.24 & $133.0 \mathrm{~d}$ & 10.39 & 3.060abcd & 0.42 & $2.520 f$ & 0.60 \\
\hline & Mean & 9.42 & 2.51 & 97.75 & 11.88 & 148.70 & 15.19 & 2.63 & 0.45 & 3.94 & 0.88 \\
\hline & Kachorwa, Bara & & & & & & & & & & \\
\hline 1 & $\begin{array}{l}\text { Harihar Tagwa } \\
\text { Bhadaiya }\end{array}$ & $8.30 \mathrm{~b}$ & 0.71 & 103.1abcde & 24.70 & $167.0 \mathrm{a}$ & 2.83 & 2.450 cde & 0.12 & $4.340 \mathrm{bcde}$ & 0.57 \\
\hline 2 & Ujarka-B & $8.00 \mathrm{~b}$ & 0.00 & $87.30 \mathrm{cde}$ & 10.97 & 149.3abcd & 16.07 & $2.560 \mathrm{bcde}$ & 0.20 & $4.230 \mathrm{bcde}$ & 0.12 \\
\hline 3 & Lamka Ujarka & 11.33ab & 6.66 & $110.0 \mathrm{abc}$ & 11.27 & $163.7 a b$ & 8.02 & $3.220 \mathrm{abcd}$ & 0.19 & 3.730de & 0.37 \\
\hline 4 & Hariharka & $12.00 \mathrm{ab}$ & 6.08 & $89.00 \mathrm{bcde}$ & 10.82 & 150.3abcd & 6.81 & $2.330 \mathrm{de}$ & 0.34 & $4.590 \mathrm{bcd}$ & 0.10 \\
\hline 5 & Ujarka-R & $15.33 a$ & 6.35 & 92.00abcde & 12.17 & $144.0 \mathrm{bcd}$ & 12.29 & $3.280 \mathrm{abc}$ & 0.68 & $4.620 \mathrm{bcd}$ & 0.54 \\
\hline \multirow{3}{*}{6} & Ujarka-N & $7.33 \mathrm{~b}$ & 0.58 & 96.70abcde & 6.11 & 155.7abc & 6.81 & $3.330 \mathrm{abc}$ & 0.34 & $4.610 \mathrm{bcd}$ & 0.41 \\
\hline & Mean & 10.38 & 3.08 & 96.35 & 8.80 & 155.00 & 8.90 & 2.86 & 0.46 & 4.35 & 0.35 \\
\hline & Pvalue & 0.203 & & 0.05 & & 0.009 & & 0.005 & & $<0.001$ & \\
\hline
\end{tabular}

$\mathrm{SN}=$ Serial number. $\mathrm{SD}=$ Standard deviation. Values followed by the same letter $/ \mathrm{s}$ are not significantly different at 0.05 level by DMRT. $d$ = Days 
Fruit characteristics and yield of sponge gourd landraces are given in Table 4 . Fruit length and fruit number per plant have been considered as important criteria for selection by sponge gourd growers. Existence of highly significant differences in these traits indicates that variation is being maintained by Kachorwa and Begnas farmers. Collections in NGB represent unique genotypes. Landraces from Begnas had longer fruits and collections from NGB had shorter fruits. Hariyo Lamo had the longest fruit, followed by Hariyo Bose. Sano Ghiraula and Sagputti Ghiraula produced the shortest fruits. Name of these landraces also indicates the length of fruits, e.g., Sano means small and Lamo means long. The landraces from Begnas had more diverse fruit length. Large genetic diversity was detected among the landraces by Bajracharya et al. (1999). Landraces from Kachorwa were not significantly different for fruit length. Fruit characters are the most important descriptors used by farmers for distinguishing and naming the sponge gourd landraces (Bajracharya et al., 1999; Pandey et al., 2003; Yadav et al., 2003).

For fruit width, collection from NGB had more variation. Collection from Begnas had landraces having fruit of similar width. Similar was the case for Kachorwa collection. Perimeter of Hariharka was the largest and that of Sano Ghiraula, the smallest.

For commercial cultivation, fruit weight is an important trait. Landraces from Begnas had higher fruit weight than the others. The heaviest fruit was produced by Lamo Bose, followed by Seto Basaune. Sano Ghiraula and Sagputti Ghiraula produced the lightest fruits. Single fruit weight in these landraces ranged from 49 to 334.3 g. Fruit weight was not significantly different among landraces of Kachorwa (Table 4). Fruit number was a relatively more important criterion for farmers. More variation in fruit number was found in NGB collections. This may be because of collections being from different locations. Fruit number was not significantly different among landraces of Begnas and Kachorwa. Number of fruits per plant ranged from 5 to 74. Sano Ghiraula produced the highest number of fruits per plant. Sano Ghiraula and Sagputti Ghiraula were the two landraces that produced significantly higher number of fruits than others. The lowest fruit number was produced by Harihar Tagwa Badaiya. Landraces having longer fruit size produced lower number of fruits $\left(r=0.44^{* *}\right)$.

Three landraces, Hariharka, Basmatiya and Lamka Ujarka, were characterized by Yadav et al. (2003). Variation was reported in Lamka Ujarka for leaf and node characteristics. Yadav et al. (2003) reported fresh fruit yield of $241.54 \mathrm{~g}$ and $166.14 \mathrm{~g}$ in Lamka Ujarka and Hariharka, respectively. Chitkavra had the fresh fruit weight of $300 \mathrm{~g}$ in Kachorwa (Yadav et al., 2003). Pandey et al. (2003) characterized five landraces (Basaune, Hariyo Chhoto, Hariyo Lamo, Lamo Bose and Seto Lamo) on-farm, out of which, Hariyo Chhoto was the most preferred one, followed by Hariyo Lamo and Basaune in Begnas. Seto Lamo and Basaune were reported as rare landraces. They also reported both inter and intra landrace diversity with most of the landraces having high productivity. Hariyo Chhoto was an early fruiting landrace with prolonged fruiting and remained tender for long period. Hariyo Lamo had long fruit with good yield. Seto Chhoto was less spongy and took relatively short time for cooking. However, the vines produced less number of fruits and set sponge early. 
Table 4. Fruit characters and yield of sponge gourd landraces

\begin{tabular}{|c|c|c|c|c|c|c|c|c|}
\hline \multirow[t]{2}{*}{ Landrace } & \multicolumn{2}{|c|}{ Fruit length, cm } & \multicolumn{2}{|c|}{ Fruit weight, g } & \multicolumn{2}{|c|}{ Fruit /plant, n } & \multicolumn{2}{|c|}{ Fruit yield/plant, g } \\
\hline & Mean & SD & Mean & SD & Mean & $\mathrm{SD}$ & Mean & SD \\
\hline \multicolumn{9}{|l|}{ Begnas, Kaski } \\
\hline Hariyo Chhoto & 17.11def & 0.54 & 160.2bcdef & 29.60 & $13.00 \mathrm{c}$ & 11.84 & 2684abc & 2739.00 \\
\hline Hariyo Basaune & $25.45 a b c$ & 3.38 & $248.2 a b c$ & 65.20 & $9.800 c$ & 4.99 & $2160 a b c$ & 874.00 \\
\hline Hariyo Lamo & $29.45 a$ & 6.02 & $255.3 a b$ & 114.80 & $8.900 c$ & 2.18 & 2019abc & 528.00 \\
\hline Lamo Bose & 27.91ab & 4.12 & $334.3 a$ & 209.00 & $1.300 c$ & 3.18 & $6450 c$ & 631.00 \\
\hline Hariyo Bose & $28.45 a$ & 5.17 & 225.3abcd & 18.10 & $10.20 c$ & 2.80 & 2255abc & 716.00 \\
\hline Seto Bose & 28.05ab & 4.30 & $282.9 \mathrm{ab}$ & 48.00 & $11.30 c$ & 7.05 & $2352 a b c$ & 1272.00 \\
\hline Seto Lamo & $28.28 \mathrm{ab}$ & 6.01 & 249.2abc & 107.50 & $12.40 \mathrm{c}$ & 5.64 & $3104 a b c$ & 1560.00 \\
\hline Seto Basaune & $27.33 \mathrm{abc}$ & 1.59 & $269.0 \mathrm{ab}$ & 42.10 & $18.60 \mathrm{bc}$ & 7.96 & 4606ab & 2195.00 \\
\hline Basaune & $26.25 \mathrm{abc}$ & 1.25 & 200.0abcd & 27.20 & $6.000 c$ & 3.50 & $1725 \mathrm{bc}$ & 1530.00 \\
\hline Mean & 26.48 & 3.71 & 247.16 & 49.60 & 10.17 & 4.78 & 2394.44 & 1072.62 \\
\hline \multicolumn{9}{|c|}{ NGB, Khumaltar } \\
\hline Jhingani & 15.58efg & 0.72 & 106.5def & 68.20 & $19.70 \mathrm{bc}$ & 15.04 & $1722 \mathrm{bc}$ & 1525.00 \\
\hline Toriya & 16.33def & 1.44 & 188.9bcde & 12.73 & $32.70 b c$ & 5.13 & $5337 a$ & 1299.00 \\
\hline Jangali Ghiraula & $13.75 f g$ & 2.22 & 173.8bcdef & 59.90 & $30.50 \mathrm{bc}$ & 18.20 & 4958ab & 2036.00 \\
\hline Jhimni & $13.23 \mathrm{fg}$ & 3.18 & $112.9 \mathrm{cdef}$ & 16.30 & $19.60 \mathrm{bc}$ & 9.90 & 2839abc & 2167.00 \\
\hline Sano Ghiraula & $11.38 \mathrm{fg}$ & 0.85 & $49.00 f$ & 12.80 & $74.60 \mathrm{a}$ & 80.60 & 2299abc & 2171.00 \\
\hline Sagputti Ghiraula & $9.850 \mathrm{~g}$ & 0.61 & 63.00ef & 12.13 & $46.60 \mathrm{~b}$ & 31.80 & $3105 a b c$ & 2389.00 \\
\hline Mean & 13.35 & 2.46 & 115.68 & 56.66 & 37.28 & 20.82 & 3376.67 & 1456.41 \\
\hline \multicolumn{9}{|c|}{ Kachorwa, Bara } \\
\hline $\begin{array}{l}\text { Harihar Tagwa } \\
\text { Bhadaiya }\end{array}$ & 21.11cde & 2.95 & 219.5abcd & 110.40 & $5.000 \mathrm{c}$ & 2.60 & $957.0 \mathrm{c}$ & 733.00 \\
\hline Ujarka-B & 26.61abc & 3.29 & 224.2abcd & 75.50 & $9.300 \mathrm{c}$ & 2.00 & 2377abc & 786.00 \\
\hline Lamka Ujarka & 23.89abc & 3.78 & $251.8 \mathrm{ab}$ & 79.70 & $12.60 \mathrm{c}$ & 10.06 & $2744 a b c$ & 2385.00 \\
\hline Hariharka & 21.05cde & 3.93 & 223.4abcd & 52.90 & $12.10 \mathrm{c}$ & 7.35 & $2456 a b c$ & 1707.00 \\
\hline Ujarka-R & $27.36 \mathrm{abc}$ & 1.33 & 257.1ab & 51.70 & $9.700 c$ & 5.45 & $1815 \mathrm{bc}$ & 1203.00 \\
\hline Ujarka-N & 23.67abc & 2.89 & 213.1abcd & 26.50 & $13.20 c$ & 7.69 & 3693abc & 2684.00 \\
\hline Mean & 23.95 & 2.66 & 231.52 & 18.27 & 10.32 & 3.05 & 2340.33 & 916.18 \\
\hline$P$ value & $<0.001$ & & 0.001 & & 0.002 & & 0.05 & \\
\hline
\end{tabular}

$\mathrm{SN}=$ Serial number. SD = Standard deviation. Values followed by the same letter/s are not significantly different at 0.05 level by DMRT.

Farmers usually maintain 1 to 5 plants per household. Therefore, fruit yield per plant is important rather than yield per hectare. On an average, NGB collections produced more fruits than Begnas collections. More variation in fruit yield was also in NGB collections (Table 4). The highest fruit yield was produced by Toriya, followed by Jangali Ghiraula and Seto Basaune. Lamo Bose gave the lowest fruit yield. Significant fruit yield was not observed within Kachorwa landraces. Among Kachorwa landraces, Ujarka-N produced the highest fruit yield per plant. The highest fruit yielder among Begnas landraces was Seto Basaune. 
Single plant of landraces can cover a large area if provided enough support. Farmers support vines with tall and large dead branch of trees. Sometimes a single plant can cover entire roof area of a house. In such cases, these landraces may produce higher fruit yield than we have reported here. We supported vines by small dead guava branches. It is likely that because of this restriction on expansion of vines, these landraces may not have yielded to their full potential.

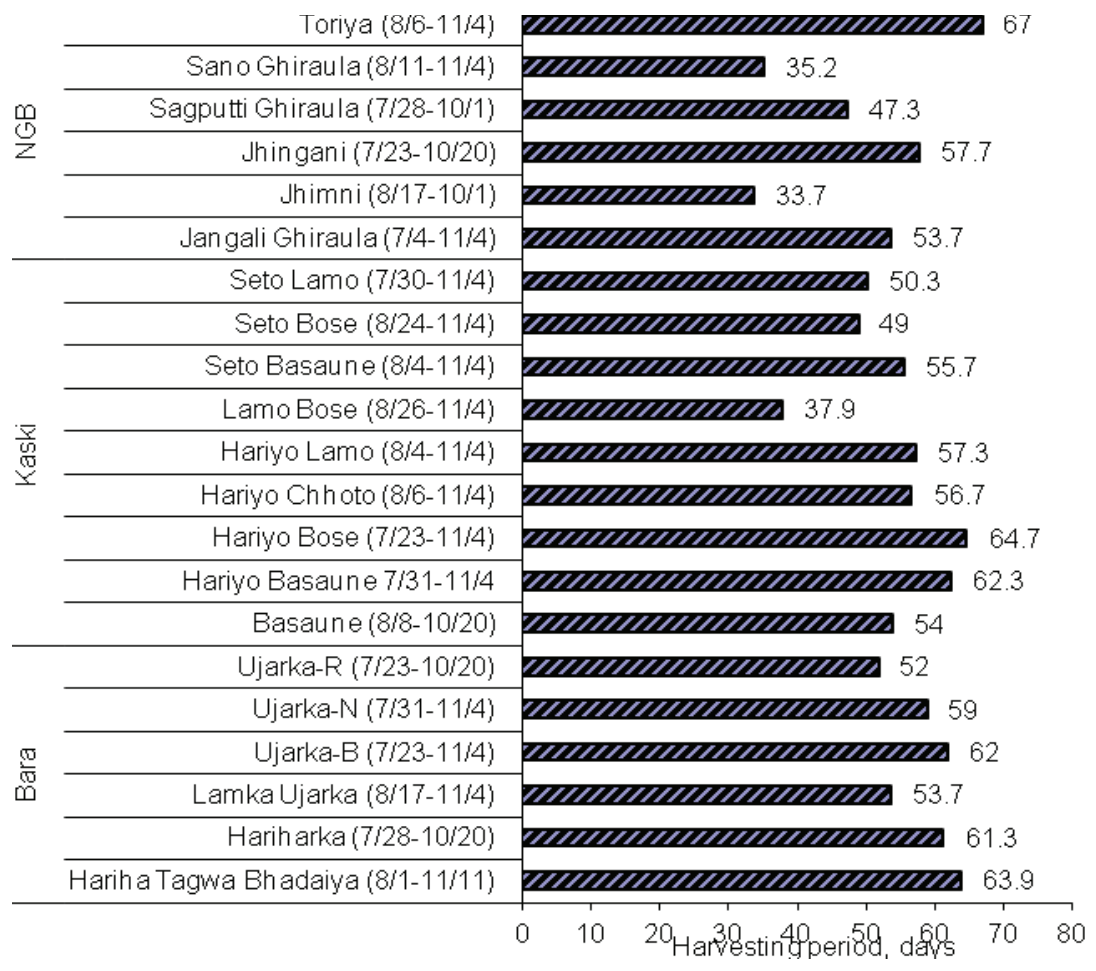

Figure 2. Fruit harvesting period of different landraces of sponge gourd collected from Bara and Kaski districts and National Genebank (NGB), Khumaltar, Nepal.

\section{CONCLUSIONS}

There were significant differences among the landraces relative to diversity studied for farmer's preferred traits, e.g., tender fruit yield, fruit weight and fruit harvesting period. Because of diverse needs of farmers in diverse environments, different landraces are being maintained. Options for improving these landraces exist by reshuffling promising attributes e.g. flesh thickness, fruit size and fruit harvesting period, etc. Landrace improvement is another option for better crop harvest. Strategy of maintaining seeds by individual farmers themselves should be considered for conserving landrace diversity on-farm.

\section{ACKNOWLEDGEMENTS}

This study was financially supported by Directorate General for International Cooperation, Netherlands and International Development Research Centre, Canada. We thank S.P. Dahal, I.P. Poudyal, S.R. Subedi, B.B. BC, P. Shrestha, A. 
Subedi and A. Mudwari for trial management, data collection, suggestions and comments. We express sincere gratitude to the farmers of Begnas and Kachorwa for providing seeds of sponge gourd landraces.

\section{REFERENCES}

Bajracharya, J., D.K. Rijal, S.P. Khatiwada, C.L. Poudel, M.P. Upadhyay, Y.R. Pandey, P.R. Tiwari, R.B. Yadav and P. Chaudhary, 1999. Farmer selection of germplasm using agromorphological and isozyme characteristics. In:B. Sthapit, M. Upadhyay and A. Subedi (eds.), A Scientific Basis of In-situ Conservation of Agrobiodiversity On-farm. Nepal's Contribution to the Global Project. NP Working Paper No. 1/99. Kathmandu. NARC, LIBRID and IPGRI, pp.49-66.

Cruz, V.M.V., M.I.S. Tolentino, N.C. Altoveros, M.L.H. Villavicencio, L.B. Siopongco, A.C. dela Vitia and R.P. Lande, 1997. Correlations among accessions of Southeast Asian Luffa genetic resources and variability estimated by morphological and biochemical methods. Philipp. J. Crop Sci. 22:131-140.

Davis, J.M., 1996. Luffa sponge gourd production practices for temperate climates. Vegetable, Production and Marketing News 6:1-3.

Gupta, S.R., M.P. Upadhyay, D.M. Dongol (eds.), 2000. Nepalese Germplasm Catalogue2000. Agriculture Botany Division-NARC, Kathmandu.

Joshi, B.K., H.B. KC, R.K. Tiwari, M. Ghale, B.R. Sthapit and M.P. Upadhyay, 2004. Descriptors for Sponge Gourd (Luffa cylindrica (L.) Roem). NARC, LIBIRD and IPGRI, Kathmandu.

Joshi, B.K., H.B. KC, R.K. Tiwari, P. Shrestha, R. Amagain and M.P. Upadhyay, 2005. Varietal richness of agricultural crop species and farmers' preferred traits over space and time in Nepal. Botanica Oreintalis 5:10-20.

NARC, 2000. Released and Registered Crops Varieties in Nepal 1960-2002 AD. Nepal Agricultural Research Council, Khumaltar, Nepal.

Pandey, Y.R., D. Rijal, M.P. Upadhyay, B. Sthapit and B.K. Joshi, 2003. In-situ characterization of morphological traits of sponge gourd at Begnas, Kaski, Nepal. In: B.R. Sthapit, M.P. Upadhyay, B.K. Baniya, A. Subedi and B.K. Joshi (eds.), On-farm Management of Agricultural Biodiversity in Nepal: Proceedings of a National Workshop, 24-26 April 2001 Lumle, NARC, LIBIRD and IPGRI, Kathmandu, pp.63-70.

Porterfield, W.M., 1955. Loofah: The sponge gourd. Econ. Bot. 9:211-223.

Rana, R.B., D.K. Rijal, D. Gauchan, B.R. Sthapit, A. Subedi, M.P. Upadhyay, Y.R. Pandey and D.I. Jarvis, 2000a. In-situ crop conservation: Findings of agro-ecological, crop diversity and socio-economic baseline survey of Begnas ecosite, Kaski, Nepal. NP Working Paper No. 2/2000, NARC, LIBIRD and IPGRI, Kathmandu.

Rana, R.B., P. Chaudhary, D. Gauchan, S.P. Khatiwada, B.R. Sthapit, A. Subedi, M.P. Upadhyay and D.I. Jarvis, 2000b. In-situ crop conservation: Findings of agro-ecological, crop diversity and socio-economic baseline survey of Kachorwa ecosite, Bara, Nepal. NP Working Paper No. 1/2000, NARC, LIBIRD and IPGRI, Kathmandu.

Singh, S.N., 1958. Studies in the sex expression and sex ratio in Luffa species. Indian J. Hort. 15:66-71.

Yadav, R., P. Chaudhary, S. Khatiwada, J. Bajracharya, R.K. Yadav, M. Upadhyay, B.R. Sthapit, A. Gautam and B.K. Joshi, 2003 Agro-morphological diversity of sponge gourd (Luffa cylindrica L.) in Bara, Nepal. In: B.R. Sthapit, M.P. Upadhyay, B.K. Baniya, A. Subedi and B.K. Joshi (eds.), On-farm Management of Agricultural Biodiversity in Nepal: Proceedings of a National Workshop, 24-26 April 2001, Lumle, NARC, LIBIRD and IPGRI, Kathmandu, pp.58-62. 